\title{
Effectiveness of Black Honey as an Antiinflammatory Substance in Rat's Wound Infected by Staphylococcus aureus
}

\author{
Fanny Gunawan $^{1}$, Willy Sandhika ${ }^{2}$, Nurul Wiqoyah ${ }^{3}$ \\ ${ }^{1}$ Medical Education Program at The Faculty of Medicine Universitas Airlangga, Surabaya, Indonesia \\ ${ }^{2}$ Departement/Medical Staff of Anatomic Pathology Faculty of Medicine, Universitas Airlangga, Dr. \\ Soetomo General Academic Teaching Hospital, Surabaya, Indonesia \\ ${ }^{3}$ Departement/Medical Staff of Microbiology Faculty of Medicine, Universitas Airlangga, Dr. Soetomo \\ General Academic Teaching Hospital, Surabaya, Indonesia
}

\begin{abstract}
Background: Black honey contains higher flavonoids, phenols, and minerals, which serves as antiinflammatory agents and promote faster wound healing. Purpose: This study aimed to determine the effectiveness of black honey on macrophage cells and blood vessels in rats' wounds infected with Staphylococcus aureus. Methods: This was an experimental study with a posttest only control group design. This study involved 24 rats divided into 4 groups. The treatment was carried out for 5 days. The rats in the K1 group were wounded (cut) and given aquadest. The rats in the K2 group were wounded (cut), infected with Staphylococcus aureus, and given aquadest. The rats in the P1 group were wounded (cut), infected with Staphylococcus aureus, and treated with $2 \mathrm{ml}$ of black honey topically. The rats in the P2 group were wounded (cut), infected with Staphylococcus aureus, and treated with $2 \mathrm{ml}$ of black honey orally. Observations were made histopathologicaly using hematoxylin-eosin (HE) staining by calculating the number of macrophage and blood vessels, and further using One-Way ANOVA. Result: The number of macrophages and blood vessels between groups was significantly different. The K2 group had the highest mean number of macrophage cells and blood vessels, and the K1 group was the least. The mean number of macrophage cells in the P1 group was more than the K1 group and less than the K2 and P2 groups, both significantly. Conclusion: Black honey was effective in reducing inflammation in wounds infected by Staphylococcus aureus.
\end{abstract}

Keywords: Black honey, anti-inflammatory, macrophage, blood vessel.

Correspondence: Willy Sandhika, Departement/Medical Staff of Pathology Anatomy Faculty of Medicine Airlangga University/Dr. Soetomo General Hospital. Jl.Mayjend Prof. Dr, Moestopo No. 6-8 Surabaya 0131, Indonesia. Phone number: +628977474175, e-mail: willysand@fk.unair.ac.id

\section{BACKGROUND}

Wound is the loss or damage of part of the body's tissue which can be caused by trauma from sharp or blunt objects, changes in temperature, chemicals, explosions, electric shocks, or animal bites. ${ }^{1}$ Ministry of Health of the Republic of Indonesia reported that incision wounds treated in Indonesian hospitals are quite high, with 250 deaths annually. ${ }^{2}$ Commonly, open cuts are infected by bacteria, parasites, or fungi. Infected wounds will cause signs such as pyrexia, pain, edema, exudate, prolonged inflammation and wound healing, and unpleasant smells. ${ }^{3}$ Wound healing consisted of3 stages: the inflammatory phase, the proliferation phase, and the remodeling phase. ${ }^{4}$ During the inflammatory phase, macrophage cells in the injured tissue will secrete proinflammatory mediators. ${ }^{5}$ During the proliferation phase, macrophages will also secrete growth factors and chemokines such as transforming growth factor (TGF), TGF- $\beta$, placental growth factors (PGF), platelet-derived growth factor (PDGF), and vascular endothelial growth factor (VEGF), which are proangiogenesis mediators to assist in the formation of new blood vessels from blood vessels around the injured blood vessels. ${ }^{6,7}$ The blood vessels are expected to help maintain the continued functioning of the injured tissues and organs. ${ }^{8}$

Some natural ingredients have been known for their properties to promote wound healing, both in sterilized and infected wounds. Honey contains flavonoids, phenols, and various minerals that serve as antioxidants, antiinflammatory, antibacterial, and strengthen the immune system to promote further wound healing. ${ }^{9}$ High osmolarity, low $\mathrm{pH}$, and hydrogen peroxide in honey also serve as effective antibacterial. ${ }^{10}$ Black honey has darker color compared and tends to taste bitter. This honey is made by Apisdorsata bees, which collect nectar from mahogany trees. ${ }^{11} \mathrm{~A}$ study reported that dark-colored honey contains higher flavonoids, phenols, and minerals compared to light-colored honey. ${ }^{12}$

Infected wounds would take a longer time to heal than uninfected wounds as intrinsic and extrinsic factors cause a longer inflammatory phase. ${ }^{6}$ This study aimed to determine the effectiveness of black honey as 
an antiinflammatory in rats' wounds infected by Staphylococcus aureus. The macrophage cells are an indicator of the inflammatory phase, and blood vessels are an indicator of the proliferation phase. This research is expected to contribute to wound healing theoretical and practical approaches, particularly those infected with Staphylococcus aureus.

\section{METHODS}

This was an experimental analytic study with a post-test only control group design. This study was carried out in the laboratory of the Department of Biochemistry, Microbiology, and Pathology Anatomy of the Faculty of Medicine, Airlangga University, in December 2019 to January 2020. The inclusion criteria were rats, males, 4-6 months old, 150-200 grams, and have no anatomical abnormality. As for the exclusion criteria, the rat did not appear to be active and died during the study. The study population was male rats (Rattus norvegicus) obtained from the experimental animal unit ofthe Biochemical Laboratory, Faculty of Medicine, Airlangga University. The rats (Rattus norvegicus) were given cut wounds at their backs. The study's provisional hypothesis was that black honey is an effective anti-inflammatory substance evidenced in a decreased number of macrophage cells and blood vessels in the histopathological preparations of the rat's skin.

This study used pure, genuine black honey, and for the standard histological method, 10\% formalin buffer solution, hematoxylin-eosin (HE) dye, paraffin, alcoholic acid, ammonia, xylol, ethanol $90 \%$ and 96\%, and distilled water. Also, bacterial colonies of Staphylococcus aureus, ketamine, xylazine (for rat anesthetic ingredients), food, and water for the rats were needed. Glass jars, funnels, thermometers, and stirrers to sterilize the honey. Deck glass, object glass, microtome, oven, paraffin molds, and tissue-specific tubes for the histological preparations. A microscope to read the results, minor surgical instruments for cutting wounds on the backs of rats, cages with drinking equipment, and bandages.

The research procedure began with the pasteurization of honey aimed to kill the pathogenic microbes without damaging the honey. This was done by heating the honey to $63^{\circ}$ Celsius for 30 minutes, soaking the honey container into ice and saltwater, and stirring the honey until it reaches room temperature. Finally, the honey was put in a sterilized jar ${ }^{15}$. Honey does not cause toxicity - both used topically and orally. However, research shows that the presence of 5hydroxymethylfurfural in honey that has been overheated and stored for too long can cause toxicity to the body characterized by nausea, vomiting, headaches, and convulsions. Therefore, honey that is not overheated and stored for too long is safe to use $\mathrm{e}^{16}$.

The bacterial preparation stage consisted of taking Staphylococcus aureus culture with inoculating loop (öse), dissolving it in $0.9 \% \mathrm{NaCl}$, stirring evenly with the vertex, adjusting the turbidity to 0.5 McFarland, applying $0.5 \mathrm{ml}$ to the wound surface, and covering the wound with bandages soaked in a bacterial solution and plaster for 24 hours. The effectivity test of black honey as an anti-inflammatory was done on 24 wounds. The rats were first adapted for 1 week, and 1-1.5 cm length and 2-3 mm depth cut wounds were made at the rats' back. The rats were then into 4 groups, each groups consists of 6 rats. The first group was the control group $1(\mathrm{~K} 1)$, and in this group, the rats were given a clean-cut and distilled water for 5 days. The second group was the control group 2 (K2), and in this group, the rats were given a cut wound infected with Staphylococcus aureus and aquadest for 5 days. The third group was the treatment group 1 (P1), and in this group, the rats were a cut wound infected with the Staphylococcus aureus and treated with $2 \mathrm{ml}$ black honey topically for 5 days. The fourth group was the treatment group $2(\mathrm{P} 2)$, and in this group, the rats were a wound cut infected with Staphylococcus aureus and treated with $2 \mathrm{ml}$ black honey orally for 5 days.

The rats' skin tissues were taken and fixed with formalin, then made histopathological preparations with HE staining were made. The number of macrophage cells and blood vessels in 3 visual fields were manually counted, add up, and averaged. This was supervised by an expert pathologist and supervisor of this study. The preparations were observed using a light microscope at a 400x magnification. The collected data were then analyzed with the ShapiroWilk normality test and One-Way ANOVA in SPSS 21.0.

This research has been approved by the Ethics Committee of the Faculty of Medicine, Airlangga University No. 240/EC/KEPK/FKUA/2019, and this study received no sponsor from any parties.

\section{RESULT}

The samples were 24 male Wistar rats, and the average body weights of the rats for each group were obtained as in Table 1. The first parameter was the number of macrophage cells. The calculation results are presented in Table 2 and Figure 1. The second parameter was the number of blood vessels or capillaries. The calculations are presented in Table 3 and Figure 2. 
Table 1. Characteristics of research subjects (Rattus norvegicus).

\begin{tabular}{lccc}
\hline \multirow{2}{*}{ Group } & $\mathrm{n}$ & \multicolumn{3}{c}{ Rat's Weight } \\
\cline { 3 - 4 } & & Mean $(\mathrm{g})$ & Std. Deviation $(\mathrm{g})$ \\
\hline Control 1 & 6 & 150.00 & 4.195 \\
Control 2 & 6 & 151.00 & 4.000 \\
Treatment 1 & 6 & 152.83 & 6.178 \\
Treatment 2 & 6 & 150.50 & 3.271 \\
\hline Total & 24 & 151.08 & 4.373 \\
\hline
\end{tabular}

Table 2. Distribution of macrophage cell count calculations.

\begin{tabular}{lllll}
\hline Group & $\begin{array}{l}\text { Mean } \\
(\text { cell })\end{array}$ & Std. Deviation & Minimum & Maximum \\
\hline Control 1 & 6.67 & 1.506 & 5 & 9 \\
Control 2 & 29.83 & 2.317 & 27 & 33 \\
Treatment 1 & 11.33 & 1.366 & 9 & 13 \\
Treatment 2 & 15.50 & 2.074 & 13 & 19 \\
\hline
\end{tabular}

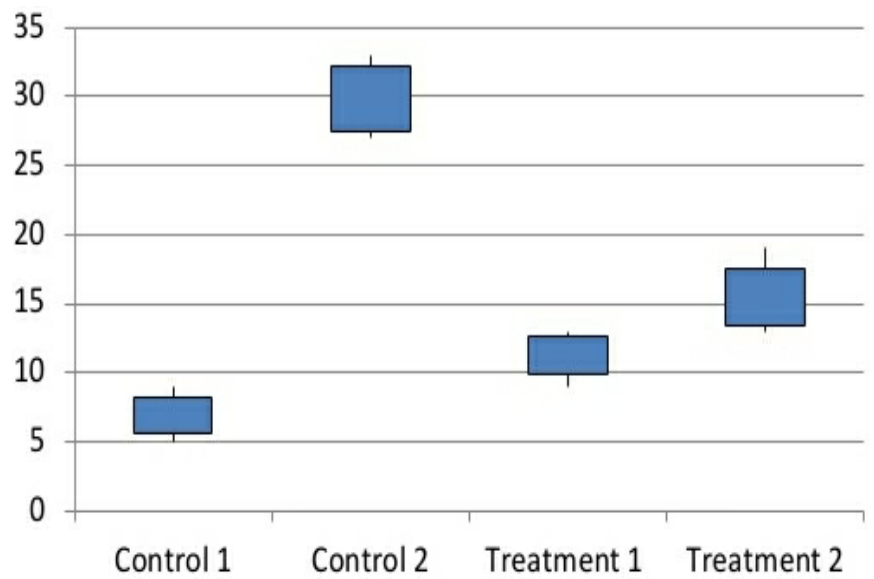

Figure 1. Comparison diagram of the number of macrophage cells between groups.

Table 3. Distribution calculation of the number of blood vessels.

\begin{tabular}{lllll}
\hline Group & $\begin{array}{l}\text { Mean } \\
\text { (cell) }\end{array}$ & Std. Deviation & Minimum & Maximum \\
\hline Control 1 & 7.67 & 2.875 & 4 & 12 \\
Control 2 & 42 & 4.050 & 35 & 46 \\
Treatment 1 & 16.50 & 2.074 & 13 & 19 \\
Treatment 2 & 25.83 & 2.137 & 23 & 28 \\
\hline
\end{tabular}

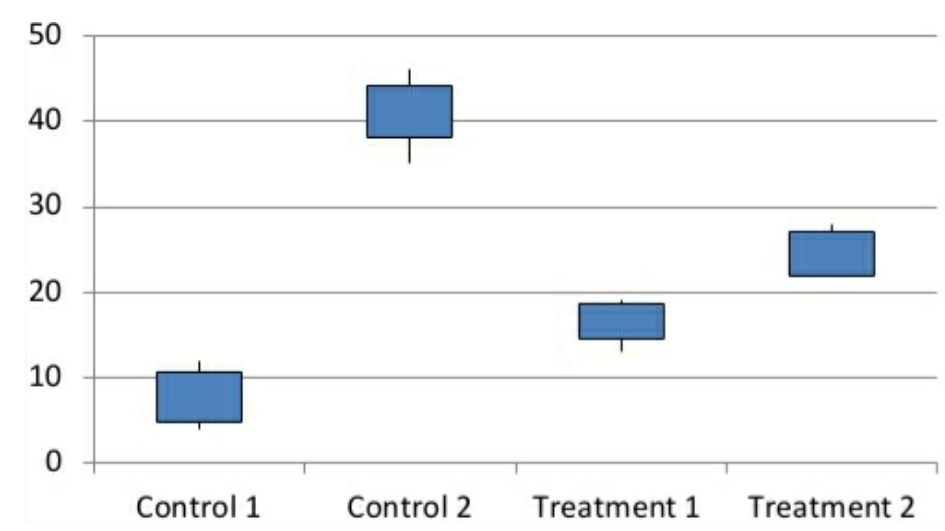


Figure 2. Comparison diagram of the number of blood vessels between groups.

The normality test results of the Shapiro-Wilk test showed that macrophage and blood vessel calculation data in all groups had a p-value $>0.05$, indicating that the data was normally distributed. The homogenity test results of the Levene's showed that macrophage and blood vessel cell count data had a p-value $>0.05$ indicating that the data was homogeneous and no difference in data variations in all groups. The average number of macrophages and blood vessels that were normal and homogeneous, as evidenced in the One way-ANOVA test results. The One-way ANOVA test results on macrophage's p-value is 0.000 and the blood vessels's p-value is also 0.000 . The p-value of the tests were $<0.05$, which means that there were statistically significant differences in the number of macrophage cells and blood vessels.

Furthermore, we used the Post-Hoc test with the Bonferroni test to see which groups differed significantly from the other groups. The significance result of the Post-Hoc test is said to be significant if the $\mathrm{p}$-value $<0.05$. The Post-Hoc test results showed that the $\mathrm{p}$-value of macrophage cells was $<0.05$ in all groups, indicating a significant difference between groups. The Post-Hoc test results showed that the pvalue of blood vessels ranges from 0.000 to 0.05 in all groups, indicating a significant difference between groups.

\section{DISCUSSION}

The average number of macrophage cells and blood vessels in the $\mathrm{K} 1$ group was the lowest and significantly to other groups. On the other hand, the K2 group had the highest number of macrophage and blood vessel cells, significantly to other groups. The average number of macrophages and blood vessels can illustrate the inflammation and wound healing experienced by each group. A higher number of macrophage cells and blood vessels indicates prolonged inflammation. An infection of Staphylococcus aureus has caused a prolonged inflammation in the $\mathrm{K} 2$ group. The bacterial infection has caused an imbalance between pro-inflammatory cytokines, chemokines, proteases, and inhibitors. ${ }^{13}$ This imbalance will trigger inflammatory cells, especially neutrophil cells, to produce excessive ROS, which causes damage to extracellular membranes, cell membranes, or premature aging of cells. ${ }^{14}$ Macrophage will also produce elastase and MMP-9 and reduce MMP inhibitors level, which play an important role in reducing inflammation and usually found in atherosclerotic plaque. ${ }^{15}$ Therefore, wounds infected by Staphylococcus aureus bacteria in this study can be classified into chronic wounds that experience prolonged inflammation and longer wound healing. Meanwhile, wounds that are not infected with Staphylococcus aureus can be classified as an acute wound. ${ }^{5}$

The mean number of macrophage cells and blood vessels of the K1 group was significantly lower than the P1 and P2 groups. It indicated that the cut wounds in the K1 group were acute, and no prolonged inflammation was observed, as in the $\mathrm{K} 2$, P1, or P2 groups. The infected cut wounds in the $\mathrm{K} 2$ group were only treated with distilled water, and they had a significantly higher mean number of macrophage cells and blood vessels to the P1 and P2 groups. On the contrary, the wounds treated with black honey, as in the P1 and P2 groups, showed improvements in inflammation and wound healing marked by significantly fewer blood vessels and macrophage cells than the K2 group.

The data analysis results suggested that black honey, both used topically or orally, helped reduce inflammation and accelerate wound healing in wounds infected by Staphylococcus aureus. Previous studies have reported that honey has an anti-inflammatory effect by reducing the activity of cyclooxygenase- 1 and cyclooxygenase-2. Also, undissolved honey can reduce the concentration of prostaglandins such as prostaglandin E2 (PGE2), prostaglandin F2 (PGF2), and thromboxane $\mathrm{B} 2$ as measured in human plasma. ${ }^{17}$ Furthermore, other studies found that honey was as effective in a colitis trial treatment using prednisolone. ${ }^{18}$ Other studies have also stated that honey can reduce inflammatory mediators such as COX-2 and TNF- $\alpha$ through inhibition of the NF- $\kappa B$ pathway. It is known that the activation of the NF- $\kappa B$ pathway plays an important role in inflammatory pathogenesis. ${ }^{19} \mathrm{~A}$ study on the anti-bacterial effect of honey reported that honey could kill all bacteria used in the study in a 24-hour incubation period, including methicillin-resistant Staphylococcus aureus (MRSA) due to methylglyoxal content, defensing-1, and hydrogen peroxide contained in honey. ${ }^{20}$ Additionally, the basic composition of phenolic compounds in different varieties of honey is quite similar and includes p-coumaric acid, eugenol, ferulic acid, cafeic acid, pinobanksin, pinocembrin, chrysin, quercetin, apigenin, and naringin in diferent proportions. Gallic acid, protocatechuic acid, p-hydroxybenzoic acid, catechin, vanillic acid, syringic acid, epicatechin, pcoumaric acid, ferulic acid, rutin, quercetin, apigenin, kaempferol, and isorhamnetin also can be detected in honey. Most of which work synergistically, which are useful as antioxidants that can prevent chronic injury and prevent pathological changes. ${ }^{21}$ 
We found that the topical use of black honey significantly lower the mean number of macrophage cells and blood vessels compared to the group given black honey orally. This illustrates that topical use of black honey gives better results at reducing inflammation and accelerating wound healing compared with oral administration in wounds infected by Staphylococcus aureus. This is in line with research conducted by Khanal, Baliga, and Uppal (2010), which proves that topical use of honey reduces scarring and inflammation in mouth ulcers. ${ }^{22}$

The physicochemical nature of honey was responsible for better results in topical use compared to oral use. Honey has a very low $\mathrm{pH}$ that can kill bacteria because the atmosphere is too acidic, and the $\mathrm{pH}$ of honey promotes fibroblast activity (migration, proliferation, and organizing collagen). Similarly, high osmolarity in honey leaves very little water for the growth of microorganisms. ${ }^{9}$ The physical properties of honey also provide a protective barrier and, by osmosis, create a moist wound healing environment that does not stick to the underlying wound tissues and hydrogen peroxide $\left(\mathrm{H}_{2} \mathrm{O}_{2}\right)$ in honey is important as an antiseptic and stimulates the wound healing process. ${ }^{23}$

Blaser et al. (2007) observed the potential use of honey as a wound dressing to treat MRSA-infected surgical wound scars (which is confirmed by swabs in their study). The result showed that topical antimicrobial treatment and vancomycin intravenously have failed to eradicate MRSA, while pure or honey mixed with alginate as a wound dressing results in the eradication of MRSA and help in wound closure. ${ }^{24}$

Honey contains many useful ingredients for wound healing and reducing inflammation, but the topical use of honey has also further demonstrated better results than oral use. In clinical practice, black honey can be used as a natural source to reduce inflammation in the wound healing treatment.

However, the study's limitations were that this study used a single dose and did not compare the route of administration. Future studies are suggested to compare the doses to find out the effective dose.

This research concluded that black honey was an effective anti-inflammatory substance for a woundhealing treatment, particularly in wounds infected by Staphylococcus aureus. This is characterized by a significant reduction in the number of macrophages and blood vessels in the groups treated with black honey, both topically and orally.

\section{REFERENCES}

1. Sjamsuhidajat $\mathrm{R}$, Jong WD. Buku ajar ilmu bedah. $4^{\text {th }}$ ed. Jakarta: Penerbit Buku Kedokteran EGC; 2017.
2. Badan Penelitian dan Pengembangan Kesehatan Kementrian Kesehatan RI. Profil kesehatan Indonesia tahun 2015. Jakarta: RISKESDAS Indonesia; 2015.

3. Sunderkötter C, Becker K. Frequent bacterial skin and soft tissue infections: diagnostic signs and treatment. J Dtsch Dermatol Ges 2015; 13.

4. Landén NX, Li D, Ståhle M. Transition from inflammation to proliferation: a critical step during wound healing. Cell Moll Life Sci 2016; 73: 3861-85.

5. Bailey J. Aetiology and treatment for chronic wound. London: University of Leicester; 2013.

6. Gurtner GC, Wong VW. Wound healing: normal and abnormal. In: Thorne $\mathrm{CH}$, Beasley RW, Aston SJ, Bartlett SP, Gurtner GC, Spear SL, editors. Grabb and Smith's plastic surgery $6^{\text {th }}$ ed. Philadelphia: Lippincott Williams \& Wilkins; 2007. p.15-22.

7. Kalangi SJ. Peran integrin pada angiogenesis penyembuhan luka. CDK 2011; 38: 177-81.

8. Kuś PM, Congiu F, Teper D, Sroka Z, Jerković I, Tuberoso CI. Antioxidant activity, color characteristics, total phenol content and general HPLC fingerprints of six Polish unifloral honey types. LWT 2014; 55: 124-30.

9. Astrini D, Wibowo MS, Nugrahani I. Aktivitas anti bakteri madu pahit terhadap bakteri Gram negatif dan Gram positif serta potensinya dibandingkan terhadap antibiotik Kloramfenikol, Oksitetrasiklin dan Gentamisin. Acta Pharm Indonesia 2014; 39: 75-83.

10. Yarli N. Ekologi pohon pelawan (Tristaniopsis merguensis Griff.) sebagai inang jamur Pelawan di kabupaten Bangka Tengah. IPB Repository 2011; $1: 1$

11. Al-Farsi M, Al-Amri A, Al-Hadhrami A, AlBelushi S. Color, flavonoids, phenolics and antioxidants of Omani honey. Heliyon 2018; 4 : e00874.

12. Di Pietro LA. Angiogenesis and wound repair: when enough is enough. J Leukoc Biol 2016; 100 : 979-84.

13. Chen L, Deng H, Cui H, Fang J, Zuo Z, Deng J, et al. Inflammatory responses and inflammationassociated diseases in organs. Oncotarget 2018; 9 : 7204.

14. Demidova-Rice TN, Hamblin MR, Herman IM. Acute and impaired wound healing: pathophysiology and current methods for drug delivery, part 1: normal and chronic wounds: biology, causes, and approaches to care. Adv Skin Wound Care 2012; 25: 304. 
15. Jager NA, De Vries BM, Hillebrands JL, Harlaar NJ, Tio RA, Slart RH, van Dam GM, Boersma HH, Zeebregts CJ, Westra J. Distribution of matrix metalloproteinases in human atherosclerotic carotid plaques and their production by smooth muscle cells and macrophage subsets. Mol Imaging Biol 2016; 18: 283-91.

16. Islam MN, Khalil MI, Islam MA, Gan SH. Toxic compounds in honey. J Appl Toxicol 2014; 34: 733-42.

17. Erguder BI, Kilicoglu SS, Namuslu M, Kilicoglu B, Devrim E, Kismet K, Durak I. Honey prevents hepatic damage induced by obstruction of the common bile duct. World J Gastroenterol 2008; 14: 3729 .

18. Himaya SW, Ryu B, Qian ZJ, Li Y, Kim SK. 1(5-bromo-2-hydroxy-4-methoxyphenyl) ethanone [SE1] suppresses pro-inflammatory responses by blocking NF- $\mathrm{BB}$ and MAPK signaling pathways in activated microglia. Eur J Pharmacol 2011; 670: 608-16.

19. Al-Waili N, Salom K, Al-Ghamdi AA. Honey for wound healing, ulcers, and burns; data supporting its use in clinical practice. Sci World J 2011; 11: 776-9.

20. Church D, Elsayed S, Reid O, Winston B, Lindsay R. Burn wound infections. Clin Microbiol Rev 2006; 19: 403-34.

21. Halagarda M, Groth S, Popek S, Rohn S, Pedan V. Antioxidant activity and phenolic profile of selected organic and conventional honeys from Poland. Antioxidants 2020; 9: 44.

22. Abdulrhman M, Samir Elbarbary N, Ahmed Amin D, SaeidEbrahim R. Honey and a mixture of honey, beeswax, and olive oil-propolis extract in treatment of chemotherapy-induced oral mucositis: a randomized controlled pilot study. Pediatr Hematol Oncol J 2012; 29: 285-9.

23. Yaghoobi R, Kazerouni A. Evidence for clinical use of honey in wound healing as an antibacterial, anti-inflammatory anti-oxidant and anti-viral agent: A review. Jundishapur J Nat Pharm Prod 2013; 8:100.

24. Blaser G, Santos K, Bode U, Vetter H, Simon A. Effect of medical honey on wounds colonised or infected with MRSA. J Wound Care 2007; 16: $325-8$. 